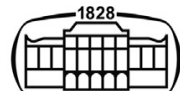

AKADÉMIAI KIADÓ

UNIVERSITY of DEBRECEN

International Review of Applied Sciences and Engineering

12 (2021) 1, 34-43

DOI:

$10.1556 / 1848.2020 .00123$

(c) 2020 The Author(s)

\title{
Integration of satellite data processing with seismic sections for tectonic interpretation and modeling for the breaks and omissions of continuous stratigraphic units
}

\author{
Rayan Gh. Thannoun ${ }^{1^{*}}$ (D), Salim A. Fanoosh ${ }^{2}$ and \\ Hadeer Gh. M. Adeeb ${ }^{3}$ \\ ${ }^{1}$ Remote Sensing Center, Mosul University, Mosul, Iraq \\ ${ }^{2}$ Petroleum and Mining Engineering College, Mosul University, Mosul, Iraq \\ ${ }^{3}$ Dams and Water Resources Research Center, Mosul University, Mosul, Iraq
}

Received: March 30, 2020 • Accepted: August 27, 2020

Published online: January 28, 2021

\section{ORIGINAL RESEARCH}

\section{PAPER}

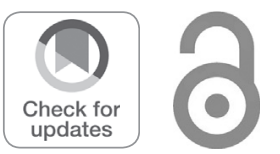

\begin{abstract}
Satellite thematic maps in geological field studies are an important tool for the delineation, interpretation, representation, and visualization of geological processes, while the development of seismic sections offers an increasingly detailed analysis of subsurface geology and inferring and understanding the subsurface structure of the earth. This combination promoted a fast-growing research in the fields of morphotectonics and neotectonics. The area under investigation is one of the most significant Iraqi places which includes several oil fields. The study area is located in northern Iraq and administratively follows Kirkuk governorate. Landscapes in this area are characterized by asymmetrical, cylindrical and extended folds. Kirkuk, Bai-Hasan and Qarachuq Anticlines reflect these structural elements and their fold axis trends towards northwest-southeast within the Zagros folded zone. The main objective of this study is to use the visual and digital interpretation of Landsat image to discriminate the sudden breaks and omissions of rock beds in the study area. Therefore, a morphotectonic map was created, the accurate location of the sudden breaks was provided and the zones affected by tectonic deformation, which left its imprint on the successive lithological units were detected. Seismic data were used to assess the tectonic impact on subsurface formations and their reflections on exposure rocks. The seismic lines were selected based on the locations of the identified sudden breaks as interpreted from satellite images. The hypothesis derived from this study is that the sudden breaks in the study area were triggered by a series of faults. In addition, the region was affected by the vertical stresses resulting from these faults and morphological aspects of the region were determined by the temporal variations of the above stresses.
\end{abstract}

\section{KEYWORDS}

remote sensing, morphotectonics, seismic sections, structural breaks, kirkuk anticline

\section{INTRODUCTION}

Remote sensing techniques like satellite images have been utilized extensively for geological purposes through the last decades, as well as they were considered essential tools for various surface and subsurface phenomena in earth sciences [1]. The strong applicability of satellite data in studying active tectonic landforms has been extensively demonstrated by previous studies [2]. One of the most widespread uses of these techniques in geology is the detection and identification of surface materials and structures. The spatial and spectral resolutions of the images have been the key factors for the discrimination of surface materials [3]. Remote sensing with geophysical data can provide more details of the subsurface structural trends and many studies relied on the integration of such data $[4,5]$. Variations in successive beds

"Corresponding author. Tel.: +9647723522669

E-mail: rayan.ghazi@uomosul.edu.iq 
lead to forming different spectra in reflected wavelengths such as those revealed by satellite images. The availability of digital image processing techniques in forming corrected enhanced and classified images have further increased the potential of remote sensing in delineating the lithological contacts and geological structures with a high efficiency and better accuracy. The successful application of remote sensing techniques in the discrimination and mapping of rock and sediment types can be used to support various activities, such as mineral exploration, oil exploration, evaluation of tectonic and structural settings, groundwater explorations, etc. The principal objective of this study is to use the visual and digital interpretation of Landsat- 8 images in discriminating the sudden breaks of rock beds at Kirkuk, Bai-Hasan and Qarachuq Anticlines. The purpose of analyzing these breaks is to prove the structural control on the successive beds. In this context, the relevance of the detected breaks to the tectonic influence domain that will be examined in this study could provide an update and new insights of the tectonic and structural framework of the study area.

\section{STUDY AREA, POSITION, AND GEOLOGICAL SETIING}

The area under investigation is located in northern Iraq and administratively follows Kirkuk governorate. This area covers about $7,200 \mathrm{~km}^{2}$ and it is situated geographically between Lat. $36^{\circ} 24^{\prime} 0.0^{\prime \prime} \mathrm{N}$, Long. $44^{\circ} 24^{\prime} 0.0^{\prime \prime} \mathrm{E}$ and Lat. $36^{\circ} 2^{\prime} 30.0^{\prime \prime} \mathrm{N}$ Long. $43^{\circ} 29^{\prime} 0.0^{\prime \prime} \mathrm{E}$. Geologically, the mountain region in the study area is characterized by asymmetrical, cylindrical, and extended folds. Several structural elements are exposed at the surface represented by the Kirkuk, Bai-Hasan, and Qarachuq Anticlines with fold axes trending northwest-southeast. The oldest exposed rocks belong to the Kirkuk formations group (Oligocene) [6] as shown in Fig. 1.

\section{DATA AND METHODOLOGY}

Subscene of multi-spectral remote sensing data (Landsat-8OLI, path 169 row 35, dated 24-8-2015) in hardcopy and digital format were carried out of some methodologies in this study. The middle infrared (band 7-R), near-infrared (band 4-G) and visible (band 1-Blue) spectral bands were used in this study. Red, Green, and Blue (RGB) color combination images of these bands were selected primarily based on the reflectance spectra of dominant rock types in the study area. The (7R 5G 2B) false color composite (FCC) Landsat-8-OLI image has been extensively used for the structural map and lithological discrimination because this combination has the advantage of preserving morphological features, as well as displaying different lithological units in different colors [7]. In the present study, the image correction and enhancement provided in ENVI software were used for enhancing and rectifying Landsat-8-OLI. The morphotectonic maps and all Landsat subscenes of the whole study area have been prepared using the software ArcGIS. Geophysical data and 2D seismic sections were used to detect the reasons for sudden breaks and omissions of stratigraphic sequences in the area under investigation. The seismic sections were made available by the Iraq North Oil Company (INOC). Seismic data give an insight into, as well as enhance the understanding of subsurface geological details, providing also information on the distribution and lateral extension of geological elements $[8,9]$.

The study was accomplished in four major stages as shown in Fig. 2. The first stage included the image for visual interpretation and applying some of the digital image processing to enhance and recognize the sudden breaks and omissions in successive beds. The second stage was performed by drawing the morphotectonic map and delineating on it the major prospected faults determined based on the spectral and morphotectonical characteristics of the exposed rocks. The third stage included the application of a geometrical correction (image to map) to achieve overlapping between the image and map. Finally, the fourth stage was to evaluate the tectonic effects on the exposed rocks and to suggested suitable structural models responsible for those tectonic effects.

\section{RESULTS AND DISCUSSION}

\subsection{Morphotectonic map}

Morphotectonic studies, conducted by researchers over the last decades, and which still brings to their attention, focused on the tectonic activity that affects the growth and development of the landform [10-15]. The study of geomorphological, stratigraphical, and tectonic analysis will provide a better understanding of the geological structures and thus provide information on the evolution of active folds [16].

Geomorphological landforms in the study area are shaped by various processes, especially structural, fluvial, and denudational ones. These processes still affect anticlines in the study area. Consequently, structural landscapes have been developed. Visual interpretation of the hardcopy Landsat image was used to prove the role of a tectonic factor and its impact on the lithological units in the Kirkuk, Bai Hasan, and Qarachuq anticlines. The importance of this interpretation is to detect the zones affected by tectonic deformation which left its imprint on the successive lithological units through cutting, displacing, and then, hiding these units. Morphotectonically, the area was divided into five units as shown in Fig. 3, as follows:

4.1.1. Outer homoclinal structure. The outer homoclinal structure of the Kirkuk, Bai-Hasan, and Qarachuq Anticlines consists of irregular areas with moderate to gentle slopes formed on resistant sandstone rocks which have been breached by stream networks. Dissected structural ridges are most common along anticline fronts where the bedding of 

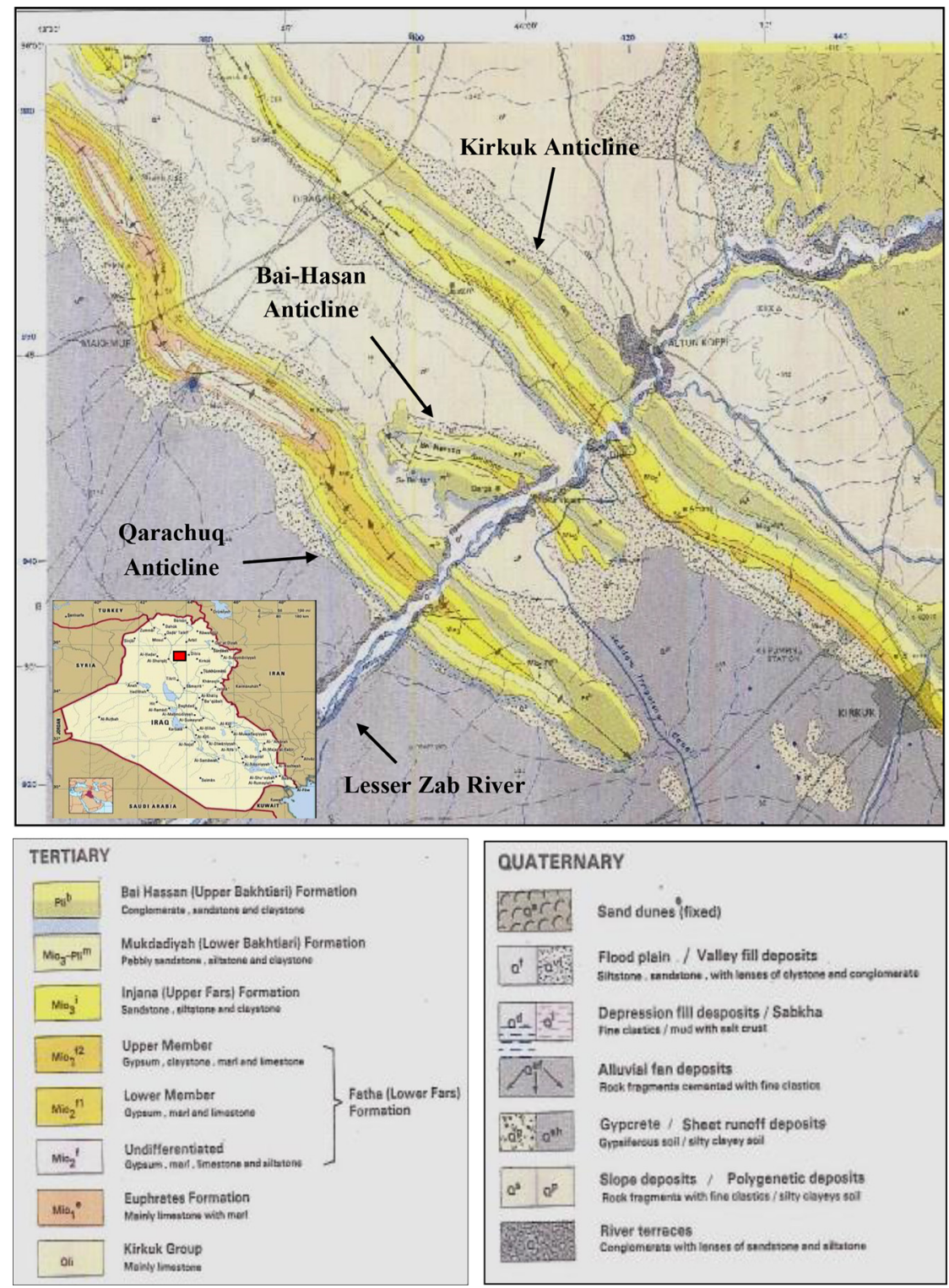

Fig. 1. Study area location and geological setting [6].

sandstone rocks dips gently to moderately on the flanks of the anticlines.

4.1.2. Middle homoclinal structure. The middle homoclinal structure of all anticlines consists of a broad area, which is the main part of these structures and formed a dissected terrain on the Injana formation (Upper Miocene). It is also characterized by gentle to moderate slopes, does not exceed $30^{\circ}$, consisting of an elliptical tectonic hill. Nevertheless, the middle homoclinal structures are higher in elevation than those in the outer ones.

4.1.3. Inner homoclinal structure. The inner homoclinal structure represents the central structural ridge of the three anticlines. It consists of a terrain with a high altitude formed on the beds of limestone alternating with marl and clay of the Fatha formation (Middle Miocene).
4.1.4. Alluvial terraces, flood plain and valley filling. Some parts of this unit in Kirkuk Anticline are affected by a major reverse fault. The distribution of homoclinal structures in the landscape reflects the role of structure and lithology in their morphological pattern. This unit appears in the visual interpretation with smooth texture, dark tone, and low incision. It is also characterized by areas of irregular strips located within the vicinity of the main channel valley (i. e. Lesser Zab River) which slopped from areas of high topography. River terraces in the study area represent topographical surfaces reflecting the levels of previous floodplains that located within the stream beds. Valley filling sediments consist of fine fluvial deposits such as clay, silt, some fragments of gravel, and conglomerates. These components are moved to the valleys through sheet and rill erosion. 


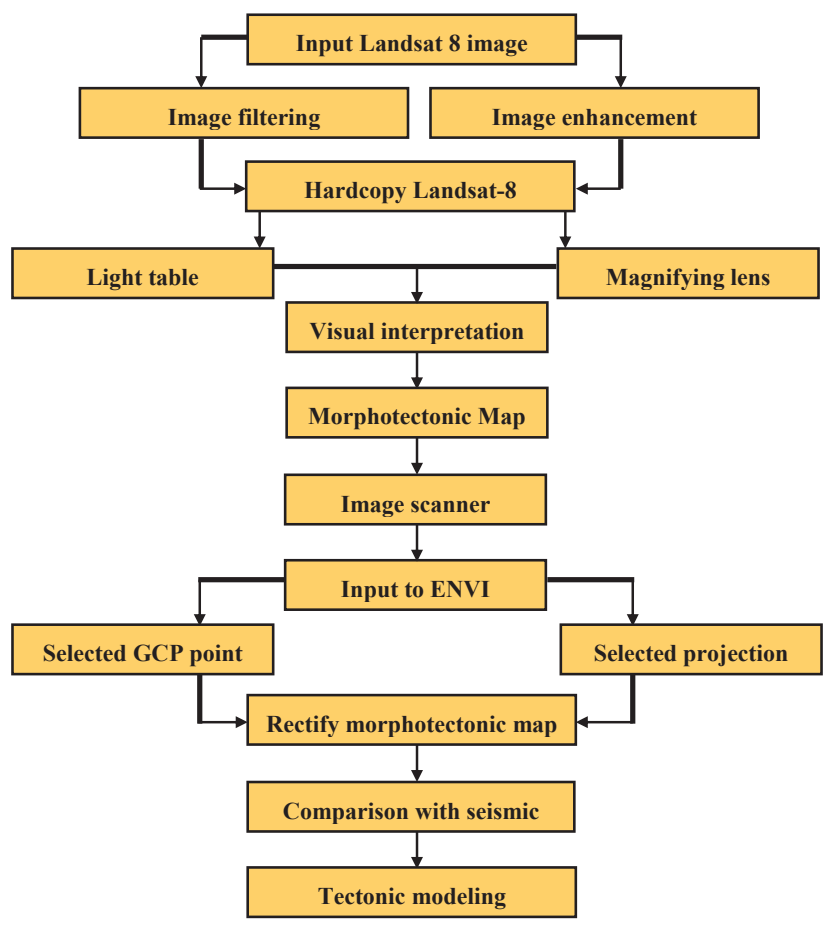

Fig. 2. Flow diagram displaying the overall methodology

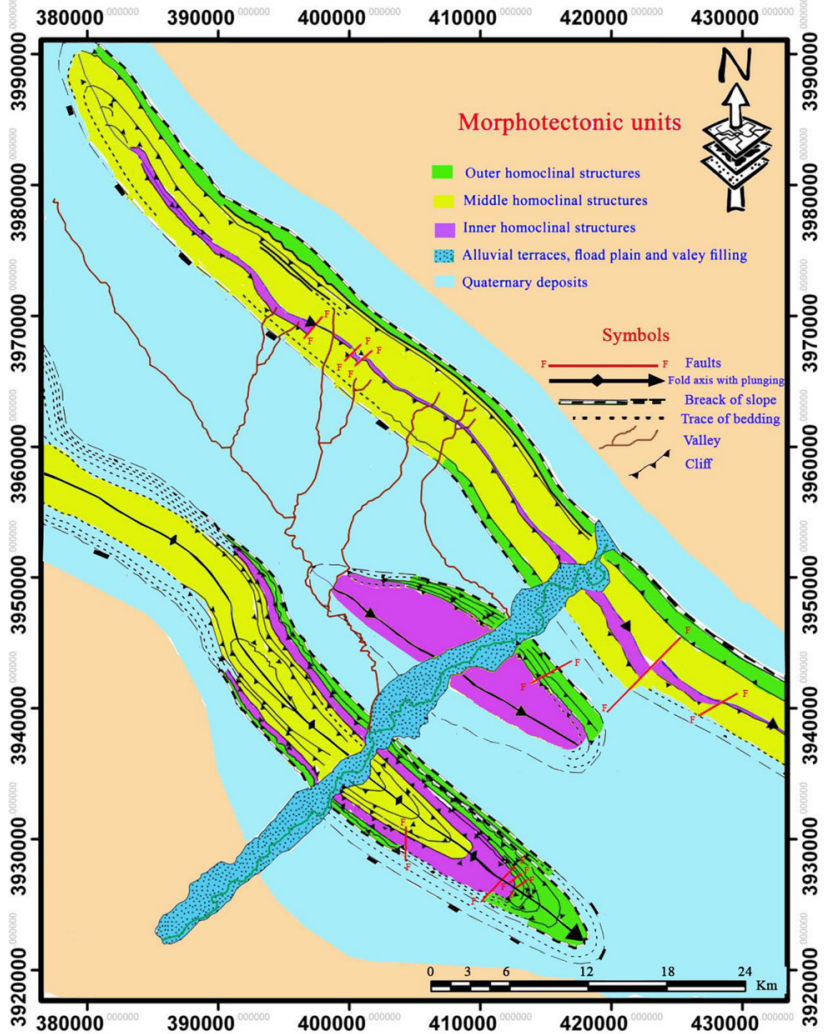

Fig. 3. Morphotectonic map of the study area

4.1.5. Quaternary deposits. These sediments cover large areas within the exposed folds and the surrounding areas. Their thickness varies from a few centimeters to several meters depending on the geological setting of the source area, location of structures, and topographical setting. However, the deposits have been formed by the weathering and erosion of the exposed formations and by the movement of eroded material and rock masses by gravity. Quaternary deposits in the study area can be classified into two units, accumulation and erosional glacis. Accumulation glacis in geomorphology represent gently sloping areas $\left(1-7^{\circ}\right)$ located at the foot slope of the main exposed structures. Whereas erosional glacis have a rolling topography and are generally located nearest to the front of the exposed structures.

\subsection{Deduced fault zones}

Many signs of structural evidence have been concluded in this study. Such evidence helps to understand and interpret the sudden changes in the stratigraphic succession at the Kirkuk, Bai-Hasan, and Qarachuq Anticlines. These changes were often caused by sets of faults induced by major and local tectonic deformation. It should be noted, however, that the faults and subtle changes in the stratigraphic succession are usually difficult to detect through ground observation because rock outcrops are often covered by soil. Several types of structural evidence revealed the relationship between the tectonic and stratigraphic sudden changes in the study area:

4.2.1. Intrafold break related faults. Morphotectonic interpretation of Landsat- 8 images helps to detect some of the fault sets within the inner and middle homoclinal structures of the exposed folds in the study area as shown in Fig. 4. The system of faults is dominated by two sets that show a systematic orientation relative to the trend of the folds axes. The first set of faults trends NE-SW Fig. 4A, B, C and $\mathrm{E}$, whereas the strikes of the other set are roughly perpendicular to the first set (i. e. NW-SE) Fig. 4D. Visual interpretation of the Landsat image clarifies that these faults resulted in a remarkable swing of the exposed ridges within the folds as shown in Fig. 4C, and other faults displaced the fold axes in Fig. 4A, D and E. In the case of Qarachuq anticline, fault sets formed horst and graben structures were affected in some parts of this anticline to be bordered on both sides by a normal fault. This resulted in a slump of some parts of the exposed rocks at the southwestern limb and consequently created sudden breaks and omissions in the stratigraphic succession (Fig. 4C). In the case of the Kirkuk and Bai-Hasan Anticlines, the interpretation showed that the faults exhibit strike-slip displacement and some of it revealed long extension (Fig. 4A and B). The local effect of these faults is the cutting and displacement of the surface rocks; in this context, some of the local breaks are also created as a result of displacement.

4.2.2. Interfold break related Faults. The structural interfold breaks, located within the outer homoclinal morphotectonic unit, are characterized by sudden breaks that extend over long distances. Complete omission of the stratigraphic sequences is observed along with these breaks at the outer limb of each fold. Conversely, intrafold breaks are 


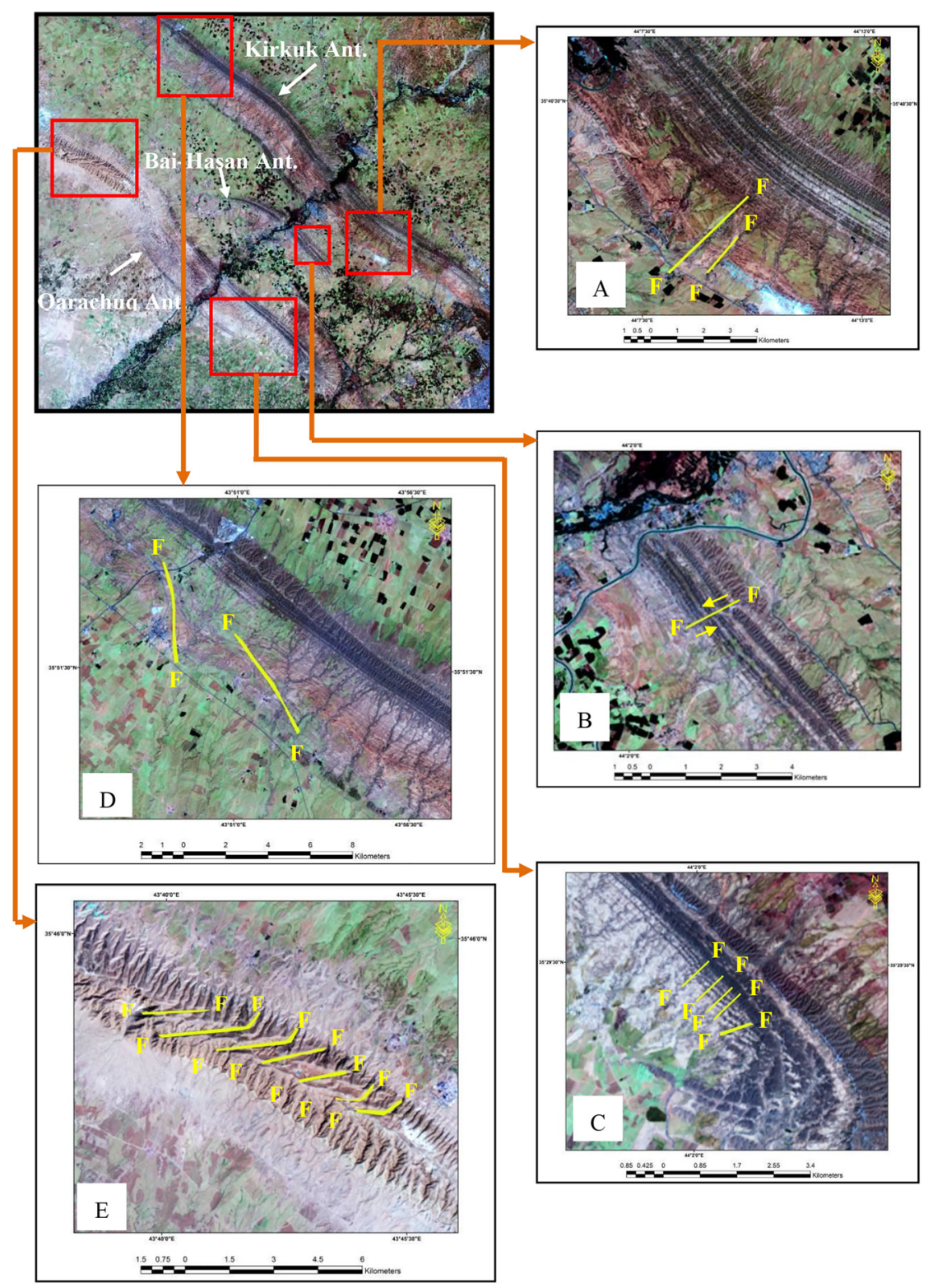

Fig. 4. Intrafold break related faults

characterized by a few long distances and no omission of the stratigraphic sequences is observed. As shown in Fig. 5, three structural interfold breaks were concluded as follows:

4.2.2.1. First break zone (Kirkuk anticline). Located at the southwestern limb of Kirkuk Anticline, the first zone is one of the distinct and sudden breaks starting from the northwestern parts of the dome Fig. 5-zone A. The zone extends toward the southwestern limb of the fold with the length of about $33 \mathrm{~km}$ ending at zone-B (Fig. 5-zone B). Another break also begins at the southwestern limb of Kirkuk fold specifically in the range directly located on the left side of Lesser Zab river Fig. 5-zone C, continuing through all parts of the southeastern limb of the fold, towards the southeastern plunge of Kirkuk Anticline, with a length of about $32 \mathrm{~km}$ to Kirkuk city. This means that the complete omitted stratigraphic succession is recorded in this part of the anticline.
4.2.2.2. Second break zone (Bai-Hasan anticline). This break extends from the northwestern to the southeastern plunge of Bai-Hasan anticline, which means that this break continues along the entire southwestern limb of the fold with a length of about $30 \mathrm{~km}$ Fig. 5-zones D and E. This indicates that complete omissions of stratigraphic succession at the southwestern limb of Bai-Hasan anticline have been recorded.

4.2.2.3. Third break zone (Qarachuq anticline). This break starts from both the northeastern and southwestern limbs of south Qarachuq anticline, near the southeastern plunge Fig. 5-zones F, G, and H, then continues along with the remaining parts of both limbs of Qarachuq anticline. From another side, on both limbs of Qarachuq anticline towards the northwestern plunge Fig. 5- zones J and I, another sudden break was determined in the stratigraphic succession of the outer homoclinal structures. 


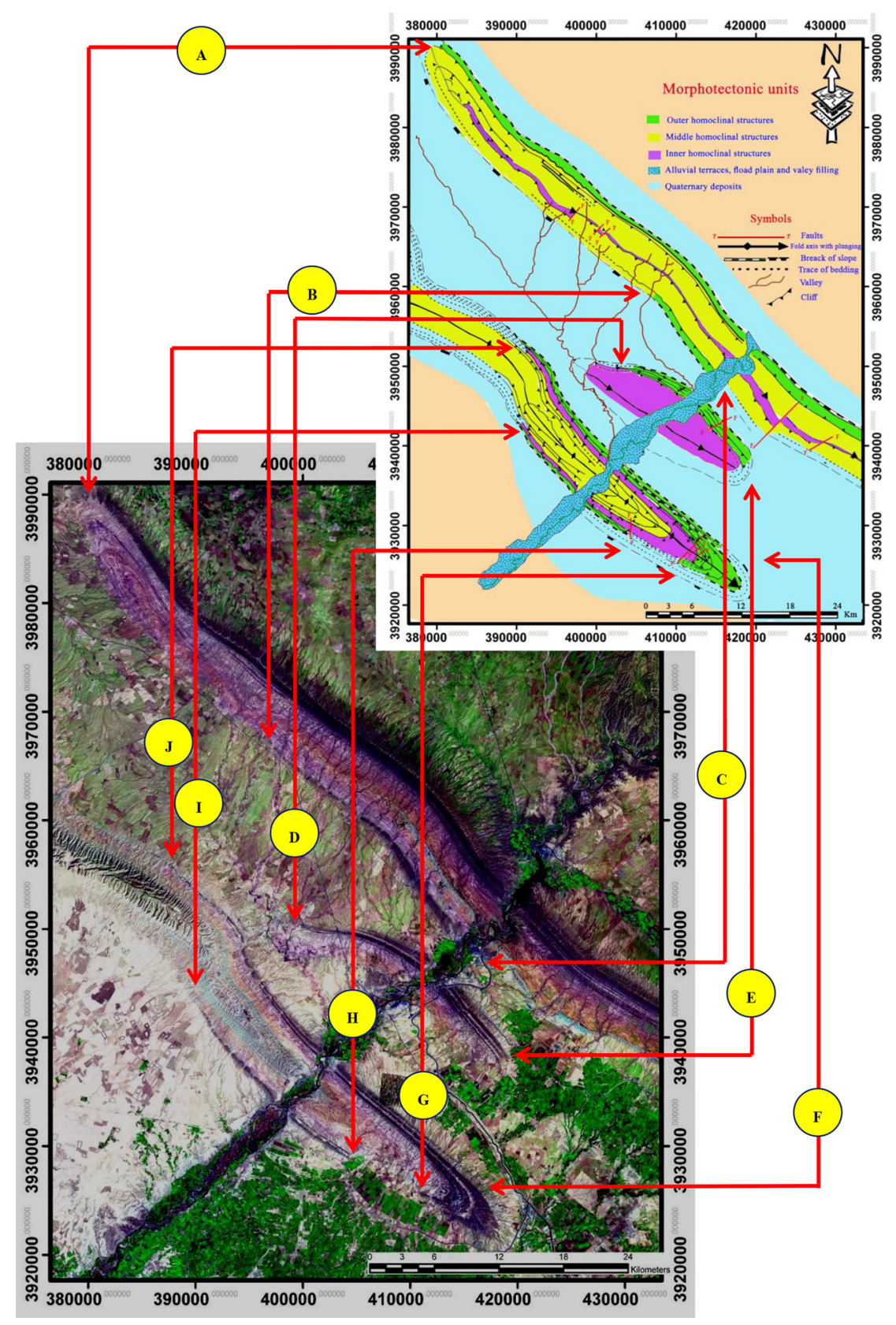

Fig. 5. Interfold break related faults

\subsection{Seismic data}

Three 2D seismic sections have relied on the study area. Seismic survey index map Fig. 6 [17], shows the direction and location of the three applied seismic sections relative to the three exposed structures (i.e. Qarachuq, Bai-Hasan, Kirkuk). As shown in the Figure above, three lines of seismic data were used to determine the tectonic factor on subsurface formation and exposure rocks. These seismic lines were chosen based on the locations of the identified sudden breaks as interpreted from satellite images in this study. Surveyed seismic lines are oriented northwest-southeast parallel to the fold axes, especially in Kirkuk and Qarachuq Anticlines, while oriented semi-parallel to the fold axes of the Bai-Hasan anticline.

\subsection{Interpretation of seismic data}

The detailed description of the $2 \mathrm{D}$ seismic sections running parallel to the exposure structures, as well as displaying subsurface formations helps to decipher the structural framework of the study area [17].

4.4.1. Seismic section A-Kirkuk Anticline. This section extends about $45 \mathrm{~km}$ northwest-southeast (as measured on the satellite image), parallel to the axis of the Kirkuk Anticline, as shown in Figs. 6 and 7, which can be divided geologically into three parts called Khurmalah, Avanah, and Baba Domes. Avanah Dome located to the northwest of the Lesser Zab River represents the middle part of the Kirkuk Anticline. While the second and third parts of the seismic 
sections include the Khurmalah and Baba Domes located to the northwest and southeast of the Lesser Zab River, respectively. The seismic section runs parallel to the axes of Khormalah and Avanah Domes, from the central parts of Khormalah Dome to cover the entire Avanah Dome, where some of the faults were interpreted in the morphotectonic

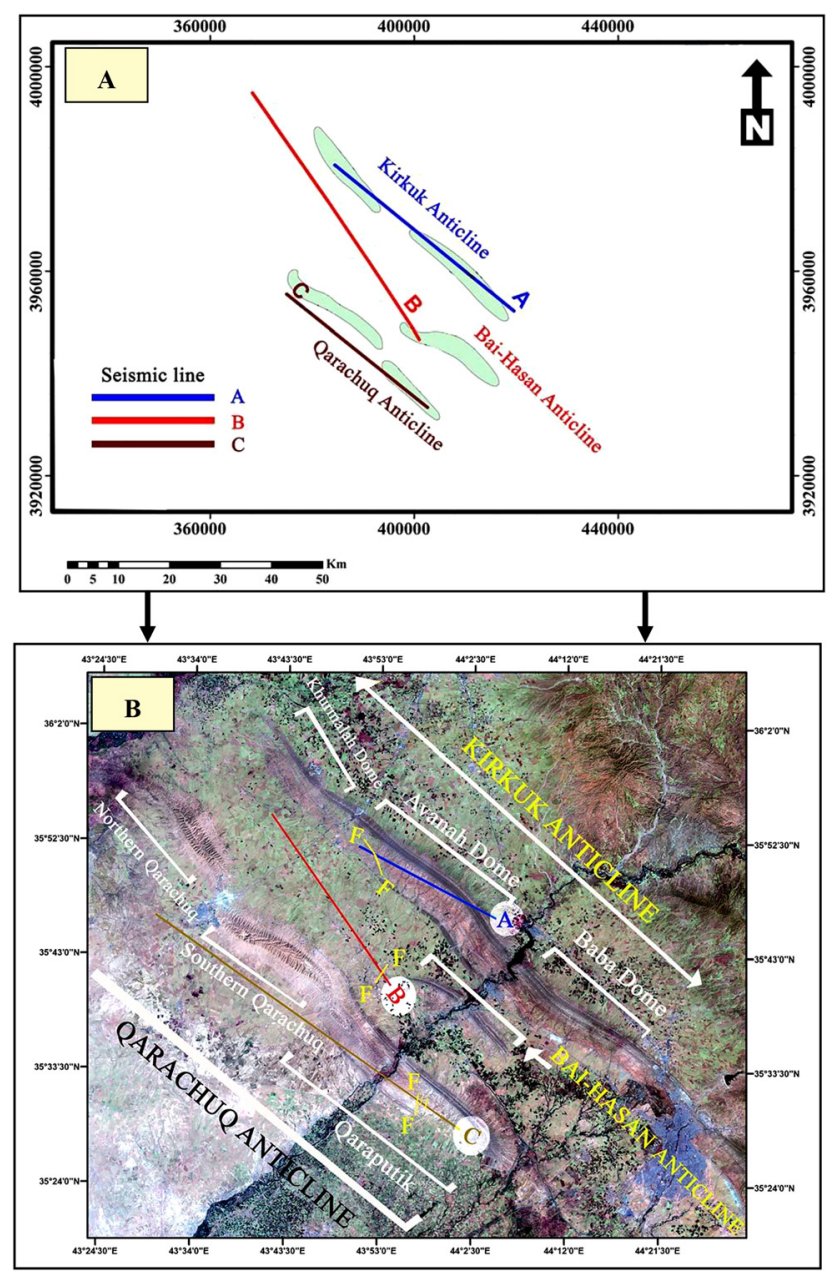

Fig. 6. A. index map [17]. B. locations of seismic lines on the satellite imagery in the study area map (Fig. 3), as well as some of them were pointed out in the map prepared by the Iraqi Geological Survey (Fig. 1). Both $[7,18]$ noted that reverse faults constitute effective hydrocarbon seepage zones. The seismic section-A, which covers the entire part of Avanah Dome, shows a strong indication to the existence of faults in this part of Kirkuk Anticline. Sudden regional breaks and omissions of stratigraphic sequences were observed along the southwestern limb of Kirkuk Anticline, whereas no seismic section was available. This required searching for other seismic sections, such as sections B and C in the two folds of Bai Hasan and Qarachuq, that at least partially reveal sudden breaks of beds in those folds.

4.4.2. Seismic section B-Bai-Hasan Anticline. This section extends for about $55 \mathrm{~km}$ in the northwest-southeast direction. Based on Figs. 6 and 8, around $5 \mathrm{~km}$ of this section covered the fold of Bai Hasan, specifically its northwestern limb reaching the core of the anticline. A sudden break of Injana formation has been indicated, as well as the omission of all stratigraphic sequences of the southwestern limb of Bai Hasan Anticline. In the southeastern part of the seismic section, it can be observed that the main cause of structural breaks for the extended beds on the northwestern limb of Bai Hasan Anticline was the high dip angle of a reverse fault. It causes to displace certain layers toward the subsurface zones leading to sudden disappearance of such layers. This explains the sudden omission of beds in this zone of the fold. It was also noticed that the distinguished fault plane exposed on the surface has led to the formation of a topographic height in the area. From the section that extends through the fold of Bai Hasan, and part of the zone outside the scope of this fold, it was observed that the study area had many subsurface structures that had been considered to be the continuous products of the Alpine Orogeny, it is the effects of which on the structures within the foreland fold belt in northern Iraq are unremitting. This was confirmed by the studies of $[7,19]$.

4.4.3. Seismic section -C- Qarachuq Anticline. The Qarachuq Anticline is situated south-west of the Kirkuk Anticline, it is an anticline with a total length of about $85 \mathrm{~km}$.

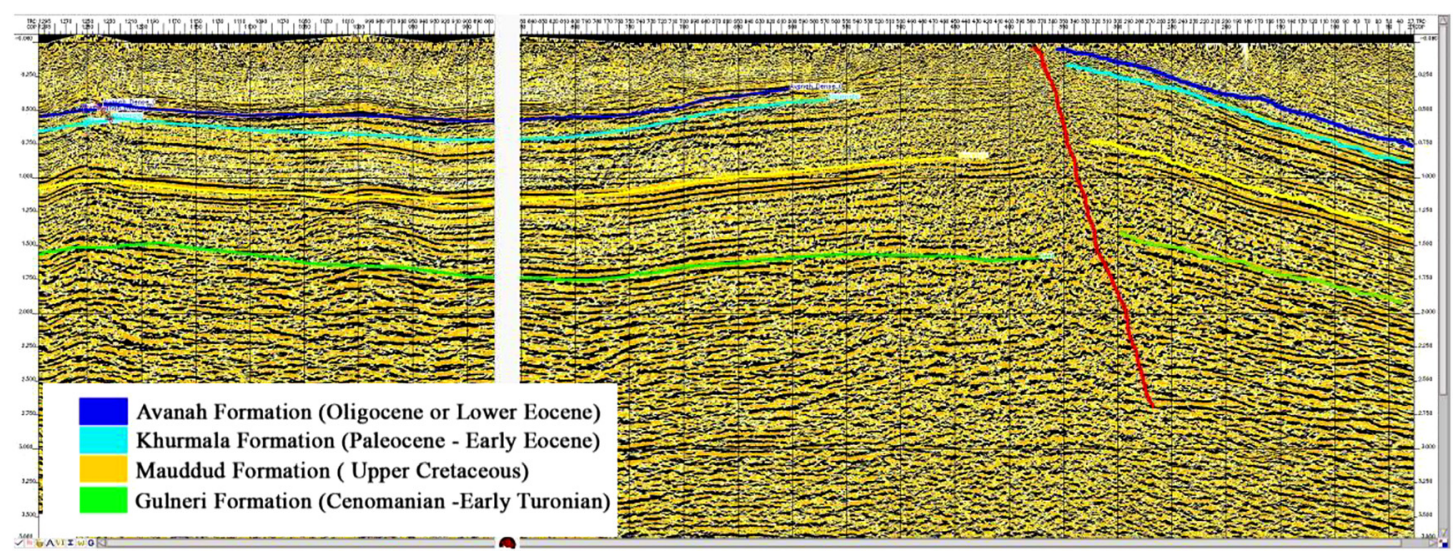

Fig. 7. Seismic section A - a part of Kirkuk Anticline [17]. 


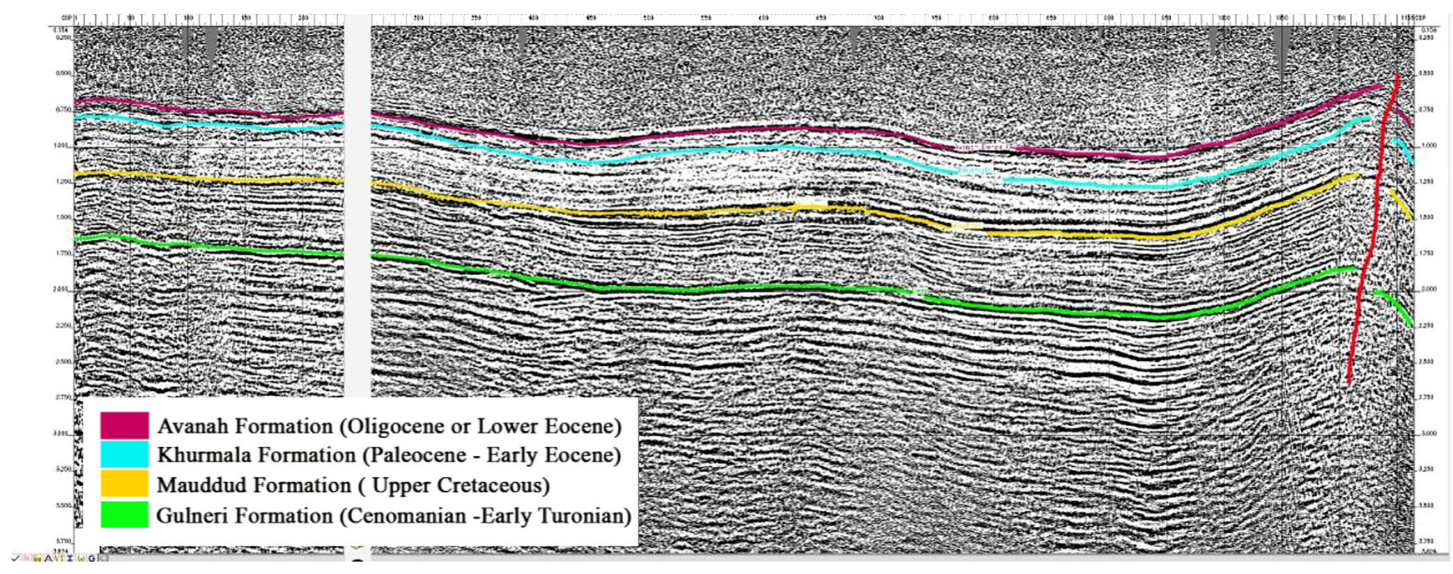

Fig. 8. Seismic section B - a part of Bai-Hasan Anticline [17].

Like the Kirkuk Anticline, the Qarachuq Anticline also consists of several parts: northern Qarachuq, southern Qarachuq, and Qaraputik Anticlines are all arranged in a dextral directional en echelon pattern. The seismic section extends for approximately $37 \mathrm{~km}$ in length in a northwestsoutheast direction (Figs. 6 and 9). It is found that the southeastern part of the Qarachuq Anticline called Qaraputik is only covered by $13 \mathrm{~km}$ of this section. It is observed through this seismic section that there are sudden breaks and omissions of the beds in some parts of the southeastern limb of this part of the anticline. The visual interpretation of the satellite images indicated many faults marked in Figs. 3 and 4. The seismic section has confirmed the presence of an area of approximately $8 \mathrm{~km}$ in which there is a clear displacement of the beds due to the presence of three planes of reverse faults. These led to the sudden subsidence of certain beds and to the uplift of other beds on the other side of the fault plane, accompanied also by an apparent topographic uplift. The impact of these faults was represented by the sudden omission of Injana formation beds in some parts of the southeastern limb of Qarachuq Anticline, as well as the emergence of a clear topographical variation in this part of the anticline.

\subsection{Tectonic model}

Structural and morphological aspects of the study area are illustrated by outcrops in some locations, by deviation in the location of folds, and by the displacement of outcrops, by the faults identified using satellite images and supported by the analysis of the seismic sections. These indicate that the study area has been subjected to more than one tectonic phase. The tectonic phases are represented by northeast-southwest and north-south stresses resulting from the collision of the Arabian and Eurasian plates. Furthermore, the study area was affected by vertical stresses as well resulting from vertical block movements. The temporal variation of the above stresses determined the stages of the structural development of the folds and morphological features in the study area. As a result, the tectonic model of the study area probably consists of two phases.

In the first phase of the tectonic model Fig. 10, the region has been subjected to northeast-southwest compression stresses due to the collision of the Arabian and Iranian plates, which led to the formation of folds, including the folds of the study area. This folding activity was accompanied by the formation of vertical joints along the fold axes.

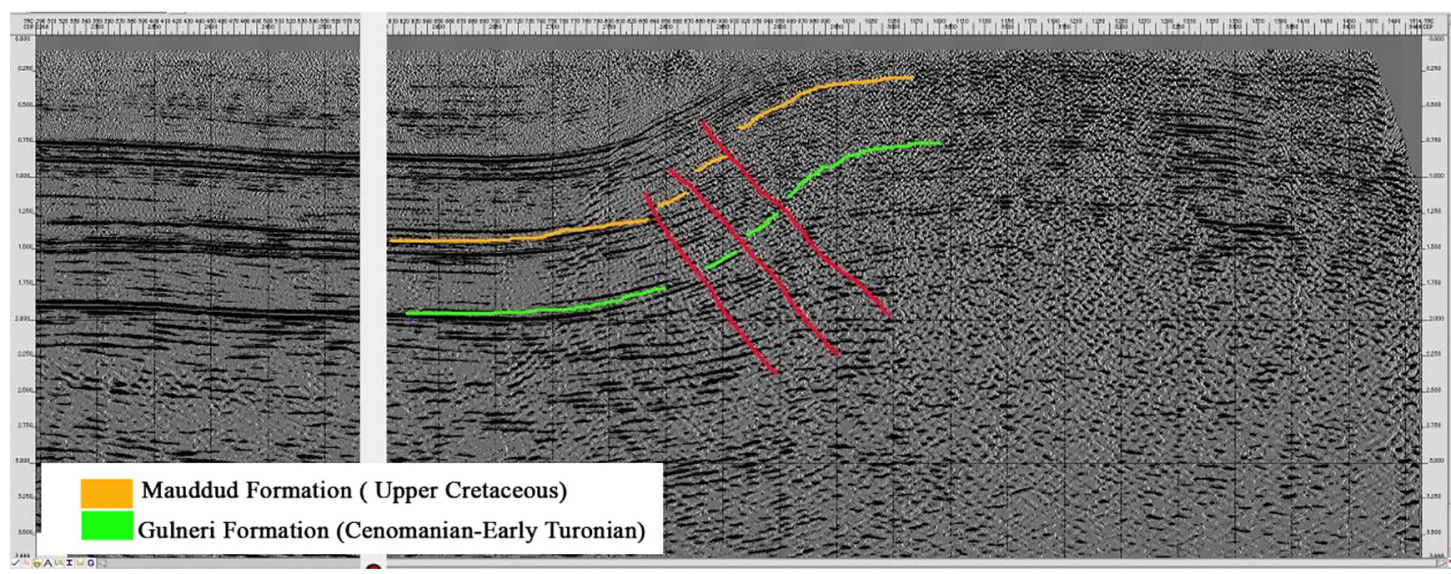

Fig. 9. Seismic section C - a part of Qarachuq Anticline [17] 

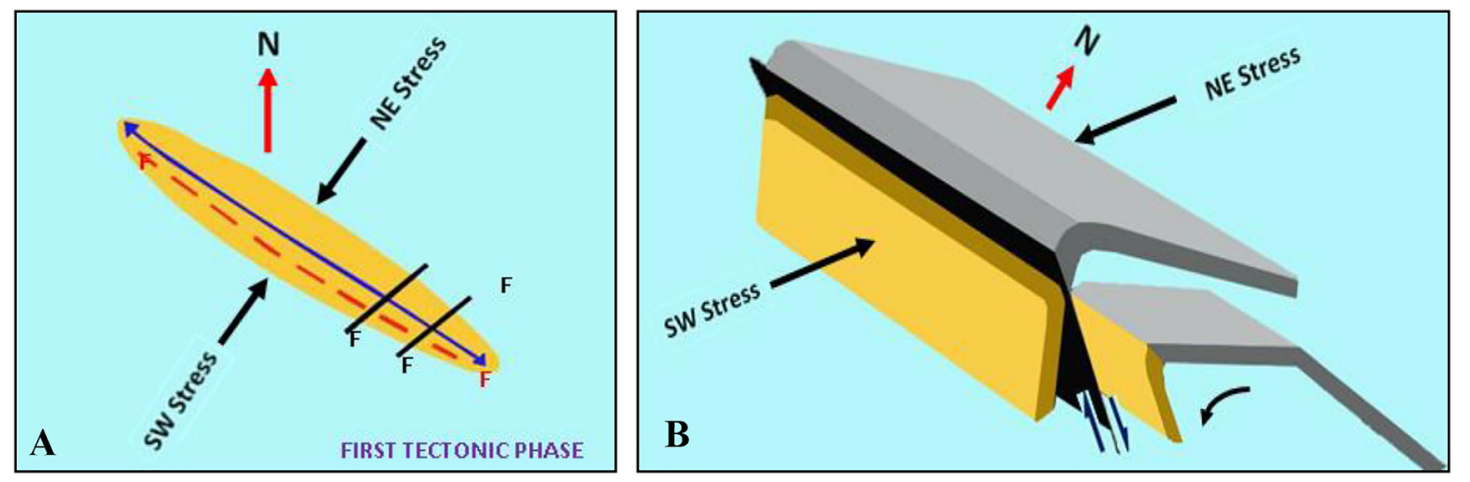

Fig. 10. A. First tectonic phase. B. Sketch diagram shows the local overturning due to torsional flexturing or rotational faulting [21]

The continued activity of the stresses led to movements along the joints of (hol) system [20], resulting in faults parallel to the fold axes. The role of these faults was revealed in the southwestern flanks of folds, by the appearance of oil seepage along outcrops in certain places [7].

In the second phase of the tectonic model (Fig. 11), the region has been subjected to north-south compression stresses due to the collision of the Arabian and Turkish plates. This collision caused movements along the surfaces of the older joints of (okl) system [20], resulting in the formation of transverse faults, that finally produced horst and graben structures. According to the type of movement, these horst and graben played a clear role in the disappearance of the outcrops in some locations of the folds and their appearance in others. The effect of these faults is proved in the studied seismic sections of the folds. At the same time, the rotation of the Arabian plate counterclockwise towards the north caused the axes of the folds in the study area to deviate from their straightness as they were in the first phase.

The tectonic model of the study area, based on the theory of the two phases of stress corresponds with the results of the geometric analysis of joints in Sheikh Ibrahim Anticline [22], and also with the results of the stress analysis of the formations in the Bashiqa Anticline, eastern Butmah Anticline, Sheikh Ibrahim Anticline and Sinjar Anticline [23]. This study indicates that the oldest formations were affected by the northeast-southwest stress, while the youngest formations were affected by the north-south stress.

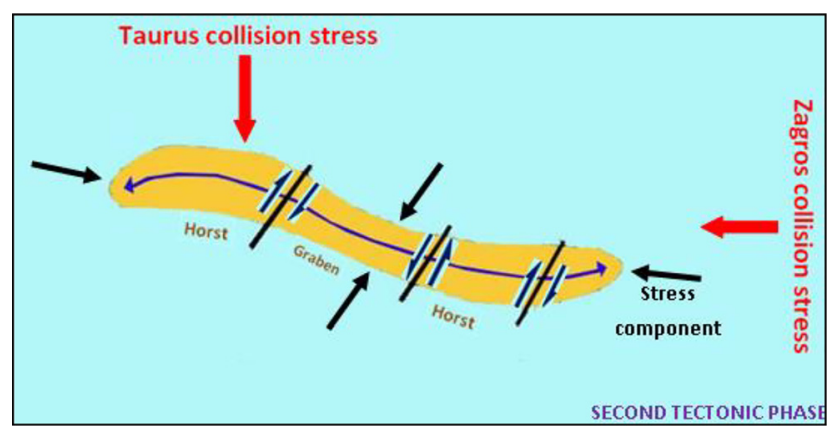

Fig. 11. Sketch diagram illustrates the second phase of the tectonic model

\section{CONCLUSION}

The integration between satellite data processing with seismic sections provides much of the information that is important to conclude the tectonic and structural setting. This study provides a significant procedure to detect sudden breaks and omissions in the stratigraphic units of Kirkuk, Bai-Hasan, and Qarachuq Anticlines. Morphotectonic map derived from the interpretation of Landsat hard copy was used to update the geological setting of the region under investigation as well as delineating morphotectonic units and then revealing the sudden breaks. By determining the relations between the sudden breaks and the seismic sections, it was found that the sub-surface formations were influenced by many faults. Consequently, the tectonic interpretation indicates that the region was subjected to more than one tectonic phase.

\section{ACKNOWLEDGMENT}

The authors are very grateful to the University of Mosul, Remote Sensing Center, Petroleum and Mining Engineering College and Dams and Water Resources Research Center for providing their facilities, which helped improve the quality of this work. In addition, we thank, the Iraqi National Oil Company-INOC, for constructive cooperation to provide us with a few seismic data.

\section{REFERENCES}

[1] S. Pirasteh, H. O. Safari, B. Pradhan, and I. Attarzadeh, "Lithomorphotectonics analysis using Landsat ETM data and GIS techniques: Zagros Fold Belt (ZFB), SW Iran," Int. Geoinformatics Res. Dev. J., vol. 1, no. 2, pp. 28-36, 2010.

[2] A. A. Shah, M. N. Zhafri, J. Delson, and B. Navakanesh, "Major strike-slip faults identified using satellite data in Central Borneo, SE Asia," Geosciences, vol. 8, no. 5, p. 156, 2018.

[3] Ü. Okyay. "Lithologic discrimination and mapping by aster thermal infrared imagery," MScThesis, METU, Geological Engineering, 2012. 
[4] E. Chinkaka, "Integrating worldview-3, aster and aeromagnetic data for lineament structural interpretation and tectonic evolution of the Haib area Namibia," Msc thesis, Enschede, The Netherlands, 70, 2019.

[5] R. K. Teruiya, W. R. Paradella, A. R. Dos Santos, R. Dall'agnol, and P. Eneziani, "Integrating airborne SAR, Landsat TM and airborne geophysics data for improving geological mapping in the Amazon region: the Cigano Granite, Caraja’s Province, Brazil," Int. J. Remote Sensing, vol. 29, no. 13, pp. 3957-74, 2008.

[6] Geosurv-Iraq, Geological map of Kirkuk Quadrangle, Sheet Ni-382, 1: 250,000, State establishment of survey and mining, Baghdad, Iraq, 1993.

[7] R. Gh. Thannoun, "Structural control evaluation of hydrocarbon seepages in northern iraq using remote sensing techniques," Ph.D.Thesis, Mosul University, Iraq, p. 222 (In Arabic with English abstract, Unpublished), 2012.

[8] M. R. Gadallah and R. Fisher, Exploration Geophysics. Verlag Berlin Heidberg, 2009, p. 292.

[9] J. Q. Ngui, M. Hermana, D. Ghosh, W. Yusof, and W. Ismail, "Integrated study of lithofacies identification-a case study in X field, Sabah, Malaysia," Geosciences, vol. 8, no. 2, p. 75, 2018.

[10] A. E. Scheidegger and S. AE, "The orientation of valley trends in Ontario," Z. Geomorphol. N.F., vol. 24, no. 1, pp. 19-30, 1980.

[11] N. S. Lanzhou and A. E. Scheidegger, "Valley trends in Tibet," Geomorphol. N.F., vol. 25, no. 2, pp. 203-12, 1981.

[12] E. Centamore, S. Ciccacci, M. Del Monte, P. Fredi, and E. L. Palmieri, "Morphological and morphometric approach to the study of the structural arrangement of northeastern Abruzzo (central Italy)," Geomorphology, vol. 16, no. 2, pp. 127-37, 1996.

[13] E. Miccadei, T. Piacentini, and M. Buccolini, "Long-term geomorphological evolution in the Abruzzo area, Central Italy: twenty years of research," Geologica Carpathica, vol. 68, no. 1, pp. 19-28, 2017.

[14]. B. Delcaillau, J. M. Carozza, and E. Laville, "Recent fold growth and drainage development: the Janauri and Chandigarh anticlines in the Siwalik foothills, northwest India," Geomorphology, vol. 76, nos 3-4, pp. 241-56, 2006.

[15]. M. S. Al-Kubaisi and M. F. A. Jabbar, "Effect of lateral propagation of selected folds on streams, Sulaimaniah area, NE Iraq," Iraqi Bulletin Geology. Mining, vol. 11, no. 1, pp. 95-124, 2015.

[16]. B. Delcaillau, B. Deffontaines, L. Floissac, et al., "Morphotectonic evidence from lateral propagation of an active frontal fold; Pakuashan anticline, foothills of Taiwan," Geomorphology, vol. 24, no. 4, pp. 263-90, 1998.

[17] B. Bulgargeomia, "Final interpretation report of seismic materials from Kirkuk area," Iraqi North Oil Company (INOC), Baghdad Iraq, 1980.

[18] S. L. Perry and F. A. Kruse, "Evidence of Hydrocarbon Seepage Using Multispectral Satellite Imagery, Kurdistan, Iraq," in AAPG International Convention and Exhibition, Alberta, Canada, Sep. 12-15, 2010, 2010.

[19]. H. Gh. M. Adeeb, "Tectogenesis of the Alpine Molasse Basin in Northern Iraq," University of Mosul, Iraq, Ph.D. thesis, 2010, p. 204. (In Arabic with English abstract, Unpublished).

[20]. A. M. Salih, "Analytical study of joints in Baba dome Kirkuk structure/northern Iraq," M.Sc. Thesis, Kirkuk University, Iraq, 2016, p. 64. (In Arabic with English abstract, Unpublished).

[21]. N. M. S. Numan and N. K. Al-Azzawi, "Structural and Geotectonic interpretation of Vergence directions of the foreland folds of Iraq," Abhath Al-Yarmouk, (Pure Science and Engineering, Yarmouk University, Jordan), vol. 2, no. 2, pp. 57-73, 1993.

[22]. S. A. K. Fanoosh, "Structural study of Sheikh Ibrahim and Mohallabiya Anticlines," M.Sc. Thesis, Baghdad University, 1989, p. 96, (In Arabic with English abstract, Unpublished).

[23]. S. A. K. Fanoosh, "Stress and strain determination of different rock types from the folded zone - Northern Iraq," Ph.D. theses, Baghdad University, Iraq, 1998, p. 202. (In Arabic with English abstract, Unpublished). 